\title{
Differences in the Anatomic Distribution of Immediate-Early Gene Expression in Amygdala and Angular Bundle Kindling Development
}

\author{
David A. Hosford, ${ }^{1,2}$ Michele Simonato, ${ }^{1}$ Zhen Cao, ${ }^{1}$ Norberto Garcia-Cairasco, ${ }^{1}$ Jon M. Silver, ${ }^{3}$ Linda Butler, \\ Cheolsu Shin, ${ }^{1}$ and James O. McNamara ${ }^{1,2,4}$ \\ Divisions of 'Neurology and ${ }^{3}$ Neurosurgery, Duke University and Durham V.A. Medical Centers, Durham, North \\ Carolina 27710 and Departments of ${ }^{2}$ Neurobiology and ${ }^{4}$ Pharmacology, Duke University Medical Center, Durham, \\ North Carolina 27710
}

Kindling is a model in which fleeting changes of neuronal activity produce a lifelong modification of neuronal structure and function in the mature nervous system. Immediate-early genes (IEGs) such as c-fos have been implicated as a causal link in the chain of molecular events coupling fleeting pathologic activity to lasting hyperexcitability. Identification of the brain structures exhibiting IEG expression during the evolution of kindling is necessary to guide investigations of the phenotypic consequences. We used in situ hybridization histochemistry to identify the structures exhibiting expression of multiple IEGs during the evolution of amygdala kindling and compared this to the pattern following angular bundle kindling. The principal findings included that: (1) generalized limbic and clonic motor (class 5) kindled seizures evoked by stimulation of one amygdala induced the expression of IEGs in a small subset of limbic structures with remarkable symmetry between the two hemispheres; (2) the anatomic extent of seizure-evoked expression of c-fos mRNA expanded progressively following focal limbic and motor (classes 0-3) seizures during the development of amygdala kindling; c-fos mRNA was detected first ipsilaterally in AM, ACO, and PC and with higher-class selzures in hippocampal formation and homologous structures contralaterally; and (3) class 5 seizures evoked by stimulation of two different sites in the limbic system (amygdala or angular bundle) induced IEG expression in distinct but partially overlapping anatomic structures. We propose that synaptic activation of glutamate receptors contributes to the expression of these diverse IEGs throughout the forebrain. The findings provide a constellation of anatomic structures in which to investigate the structural and functional consequences of IEG expression.

[Key words: kindling, amygdala, angular bundle, immediate-early genes, in situ hybridization, $c$-fos, $c$-jun, NGFIA, NGFI-B]

\footnotetext{
Received Mar. 24, 1994; revised Aug. 5, 1994; accepted Oct. 7, 1994.

We are grateful for the technical assistance provided by Lewis C. Rigsbee and for the administrative assistance provided by Rena Wethington and Betty Worrell. We thank Dr. Leonard E. White for critically reviewing the manuscript. This study was supported by grants from the NIH and the Veterans Administration (D.A.H. and J.O.M.) and from NATO (M.S.).

Correspondence should be addressed to Dr. David A. Hosford, Building 16 , Room 20, V.A. Medical Center, 508 Fulton Street, Durham, NC 27705.

Copyright (C) 1995 Society for Neuroscience $0270-6474 / 95 / 152513-11 \$ 05.00 / 0$
}

Fleeting changes of neuronal activity produce a lasting reorganization of synaptic connections in the development of the vertebrate nervous system (Hubel and Wiesel, 1965; Cline and Constantine-Paton, 1990; Shatz, 1990). Activity-dependent interactions also contribute to formation of abnormal synaptic connections in the mature nervous system (Tauck and Nadler, 1985). Kindling is one model in which fleeting changes of neuronal activity in the form of brief focal seizures lead to a lifelong functional and structural reorganization of the mammalian brain (Goddard et al., 1969; McNamara et al., 1985). Kindling is most conveniently induced by focal application of a low-intensity electrical stimulus, which initially evokes a brief, localized electrical seizure without behavioral changes, but after repeated applications, evokes prolonged, widespread electrical seizures accompanied by intense behavioral seizures. Once established, this enhanced sensitivity to electrical stimulation is lifelong. Kindling is accompanied by a lasting, activity-dependent, synaptic reorganization, one example of which is the aberrant synapses formed by mossy fiber axons of hippocampal dentate granule cells (Sutula et al., 1988; Represa et al., 1993).

Immediate-early genes (IEGs) such as c-fos provide an attractive mechanism by which fleeting alterations of neuronal activity produce lifelong synaptic reorganization through regulation of gene expression (Goelet et al., 1986). Seizures are sufficient to induce the rapid, dramatic, and fleeting expression of the IEG c-fos in discrete neuronal populations of rodent forebrain (Morgan et al., 1987; Saffen et al., 1988; Shin et al., 1990; Simonato et al., 1991). The necessary condition for induction of kindling, a brief focal electrical seizure, is sufficient to induce expression of c-fos in hippocampal dentate granule cells (Dragunow and Robertson, 1987; Morgan et al., 1987). Both circumstantial and direct evidence implicates seizure-induced c-fos expression as a causal link in the chain of molecular events culminating in kindling development (Labiner et al., 1993; Watanabe et al., 1994).

The graded development of kindling predicts that IEGs would be expressed in discrete brain structures near the stimulating electrode and/or in monosynaptic targets of these structures following the initial stimulation. Subsequent stimulations would be expected to induce IEG expression in progressively more distant but synaptically related structures. Identification of these structures is critical to elucidating the phenotypic consequences of IEG expression. We therefore examined the anatomic distribution of expression of multiple IEGs (c-fos, c-jun, NGFI-A, 
NGFI-B) induced during the evolution of amygdala kindling and compared this to the patterns induced by angular bundle kindling. We also tested the hypothesis that increased constitutive expression of these IEGs accompanies the permanence of the kindled state, by comparing IEG expression immediately following a generalized limbic and clonic (class 5) seizure to that obtained $28 \mathrm{~d}$ after the last class 5 seizure.

Preliminary results of these studies were reported earlier (Hosford et al., 1990, 1991).

\section{Materials and Methods}

Amygdaloid kindling. Male Sprague-Dawley rats (Charles River, Wilmington, $\mathrm{NC}$ ) weighing $250-275 \mathrm{gm}$ at the time of surgery were housed singly on a $12 \mathrm{hr}$ light/dark cycle and allowed free access to food and water. Under pentobarbital anesthesia $(50 \mathrm{mg} / \mathrm{kg}$, i.p. $)$, a bipolar recording electrode was stereotaxically implanted into the hilus of the dentate gyrus of left dorsal hippocampus (coordinates using instrument zero as reference: $-3.0 \mathrm{~mm}$ AP, $2.3 \mathrm{~mm}$ lateral, and $6.7 \mathrm{~mm}$ dorsal; nose bar at $-5.0 \mathrm{~mm}$ ) and a bipolar stimulating electrode was implanted into the right amygdala, using coordinates for the basomedial amygdaloid nucleus $(+3.0 \mathrm{~mm} \mathrm{AP}, 4.8 \mathrm{~mm}$ lateral, and $2.3 \mathrm{~mm}$ dorsal to instrument zero).

Following a 1 week postoperative recovery period, animals were divided into groups ( $n-5$ per group) that received either one, three, five, or seven stimulations, or a sufficient number of stimulations to induce three class 5 seizures (consisting of rearing and falling; Racine, 1972). Stimulated animals received a $60 \mathrm{~Hz}, 1 \mathrm{sec}$ train of $1 \mathrm{msec}$ biphasic square wave pulses, delivered at $500 \mu \mathrm{A}$. Afterdischarge duration (ADD) was recorded from ipsilateral amygdala and contralateral dentate hilus. Additional control animals $(n=10)$ were implanted and handled identically but were not stimulated (sham stimulation). Animals were stimulated or handled once daily through the penultimate stimulation. To ensure that the final stimulation would not be delivered during a refractory period to IEG induction (Morgan et al., 1987), the final stimulation was delivered $7 \mathrm{~d}$ following the penultimate one. All animals were sacrificed by decapitation $30 \mathrm{~min}$ after the final handling or stimulation.

Angular bundle kindling. A bipolar recording electrode was stereotaxically implanted into the right dentate gyrus of dorsal hippocampus (coordinates given above). A bipolar stimulating electrode was also placed into the right angular bundle using electrophysiologic guidance (Shin et al., 1987). Following a 1 week postoperative recovery period, animals were divided into the following four stimulated groups and one sham-stimulated group.

All stimulated animals (total $n=23$; see below) received a $2 \mathrm{sec}$ train of $1 \mathrm{msec}$ biphasic square wave pulses at $60 \mathrm{~Hz}$, delivered with intensities between 200 and $1000 \mu \mathrm{A}$; a sufficient intensity was used to ensure at least $30 \mathrm{sec}$ of $\mathrm{AD}$ to allow expression of c-fos mRNA as per Shin et al. (1990). ADD was measured from the ipsilateral dentate hilus. There were four groups of stimulated animals. Animals in the first group (henceforth designated "single AD"; $n=5$ ) were stimulated a single time and were sacriticed by decapitation $15 \mathrm{~min}$ later. The second group (henceforth designated "kindled"; $n=5$ ) was included to allow a comparison of IEG expression between animals with a single $\mathrm{AD}$, and animals that were fully kindled. Animals in this group were stimulated once daily until the development of three successive class 5 seizures, which consisted of forelimb clonus, rearing and falling ( $\mathrm{Ra}-$ cine, 1972). These animals were sacrificed $15 \mathrm{~min}$ after the last class 5 seizure. The third group $(n=8)$ was included to permit valid comparisons with amygdaloid-kindled animals that were sacrificed 30 min after the final amygdaloid stimulation (see above). Animals in this group were kindled using the same procedure as that used for the second group until the final stimulation. Then the final stimulation was delivered $7 \mathrm{~d}$ (instead of $1 \mathrm{~d}$ ) after the penultimate one, and the animals were sacrificed $30 \mathrm{~min}$ (instead of $15 \mathrm{~min}$ ) after the last class 5 seizure. The fourth group $(n=5)$ was included to measure the constitutive expression of IEGs after kindling development had occurred. These animals were stimulated until the development of three class 5 seizures, and they were sacrificed $28 \mathrm{~d}$ following the last class 5 seizure.

The sham-stimulated animals (henceforth designated "control"; $n=$ 5) were connected to the stimulus apparatus daily but were not given electrical stimulations. They were handled in a manner that differed
Table 1. Amygdala stimulation: mean induction of c-fos mRNA as a function of seizure class and afterdischarge duration

\begin{tabular}{|c|c|c|c|c|c|c|}
\hline & \multicolumn{4}{|c|}{ Number of stimulations } & \multirow{2}{*}{$\begin{array}{l}\text { Three class } \\
5 \text { seizures }\end{array}$} \\
\hline & & $\overline{1}$ & 3 & 5 & 7 & \\
\hline \multirow{2}{*}{\multicolumn{2}{|c|}{$\begin{array}{l}\text { Seizure class } \\
\text { Amygdala ADD } \\
\quad(\mathrm{sec})\end{array}$}} & 0 & 0.5 & 2.3 & 2.4 & 5 \\
\hline & & 19.6 & 34.0 & 45.6 & 62.8 & 63.4 \\
\hline \multicolumn{7}{|c|}{ Hippocampal } \\
\hline \multicolumn{2}{|c|}{ ADD (sec) } & 3.3 & 34.0 & 45.6 & 62.8 & 63.4 \\
\hline \multirow[t]{2}{*}{$\mathrm{ACO}$} & $\mathrm{R}$ & 0.5 & 0.8 & 1.6 & 1.7 & 0.8 \\
\hline & $\mathbf{L}$ & 0 & 0 & 0 & 0.7 & 0.6 \\
\hline \multirow[t]{2}{*}{$\mathrm{AM}$} & $\mathrm{R}$ & 1.0 & 0.7 & 1.5 & 1.4 & 0.9 \\
\hline & $\mathbf{L}$ & 0.2 & 0.4 & 0.4 & 0.6 & 0.5 \\
\hline \multirow[t]{2}{*}{$\mathrm{ABM}$} & $\mathrm{R}$ & 0 & 0 & 0 & 0 & 0 \\
\hline & $\mathbf{L}$ & 0 & 0 & 0 & 0 & 0 \\
\hline \multirow[t]{2}{*}{$\mathrm{ABL}$} & $\mathrm{R}$ & 0 & 0 & 0 & 0 & 0 \\
\hline & $\mathbf{L}$ & 0 & 0 & 0 & 0 & 0 \\
\hline \multirow[t]{2}{*}{ APL } & $\mathrm{R}$ & 0 & 0 & 0 & 0 & 0 \\
\hline & $\mathbf{L}$ & 0 & 0 & 0 & 0 & 0 \\
\hline \multirow[t]{2}{*}{$\mathrm{PC}$} & $\mathrm{R}$ & 1.0 & 0.9 & 1.6 & 1.4 & 0.4 \\
\hline & L & 0.1 & 0 & 0.6 & 0.7 & 0.6 \\
\hline \multirow[t]{2}{*}{ DGC } & $\mathrm{R}$ & 0 & 0 & 0.9 & 1.6 & 2.2 \\
\hline & $\mathbf{L}$ & 0 & 0 & 1.3 & 0 & 2.2 \\
\hline \multirow[t]{2}{*}{$\mathrm{CA} 3$} & $\mathrm{R}$ & 0.1 & 0.1 & 0.6 & 0.3 & 0.9 \\
\hline & L & 0.1 & 0.1 & 0.8 & 0.2 & 0.9 \\
\hline \multirow[t]{2}{*}{$\mathrm{CA} 1$} & $\mathrm{R}$ & 0.1 & 0.1 & 0.6 & 0.3 & 0.6 \\
\hline & L & 0.1 & 0.1 & 0.8 & 0.1 & 0.6 \\
\hline
\end{tabular}

Shown is the mean expression of c-fos mRNA (moles $\times 10^{-20} / \mathrm{mm}^{2}$ ) in nine neuronal populations (abbreviations same as in Fig. 6) as a function of the number of stimulations. These mean values may not correspond precisely to figures because of animal-to-animal variability. Mean seizure class (after Racine, 1972) and mean amygdala and hippocampal afterdischarge durations (ADD) are shown for each group of animals. There was no detectable constitutive expression of $\mathrm{c}-$ fos $\mathrm{mRNA}$ in any of these structures.

from stimulated animals only by the absence of electrical stimulation. They were sacrificed $15 \mathrm{~min}$ after the last sham stimulation.

Brain sections. $\Lambda$ fter sacrifice, the brains were quickly removed and frozen in isopentane chilled by a dry ice/methanol bath. Ten micrometer sections at the levels of the nucleus accumbens (see Pellegrino and Cushman, 1967, plate 18), entopeduncular nucleus (plate 32), dorsal hippocampus (plate 42), and substantia nigra (plate 48) were thawmounted onto autoclaved, gel-coated slides. Brain sections were fixed in paraformaldehyde and stored at $-70^{\circ} \mathrm{C}$ until they were used (Simonato et al., 1991). Additional sections were processed for histologic verification of the site of amygdala stimulation, as described below.

Oligonucleotide probes. Fifty-mer oligonucleotide sequences complementary to mRNA sequences within each IEG were validated for specificity of hybridization, by using Northern blotting techniques to show that each probe bound to a single mRNA of appropriate size (Simonato et al., 1991). The oligonucleotide probes for c-fos and c-jun were further validated by showing that they hybridized to the same bands to which nick-translated cDNA probes hybridized (Simonato et al., 1991). The oligonucleotide probe for NGFI-A was further validated by showing that it hybridized to the same band as an oligonucleotide probe that was complementary to a different sequence within the NGFI-A mRNA. The IEG mRNA sequences encompassed nucleotides 270-319 of rat c-fos (Curran et al., 1987), nucleotides 415-464 of human c-jun (Angel et al., 1988; also validated as a suitable probe for rat c-jun as described by Simonato et al., 1991), nucleotides 890-939 of rat NGFI-A (Milbrandt, 1987), and nucleotides 1284-1333 of rat NGFI-B (Milbrandt, 1988). These oligonucleotides were radiolabeled before each experiment by using terminal transferase to add $\alpha-{ }^{32} \mathrm{P}$-dATP $(6000 \mathrm{Ci} / \mathrm{mmol}$; DuPont-New England Nuclear, Wilmington, DE) to the $3^{\prime}$ position. The resulting radiolabeled probes had a specific activity approaching $36,000 \mathrm{Ci} / \mathrm{mmol}$.

In situ hybridization histochemistry. Each section was prehybridized 


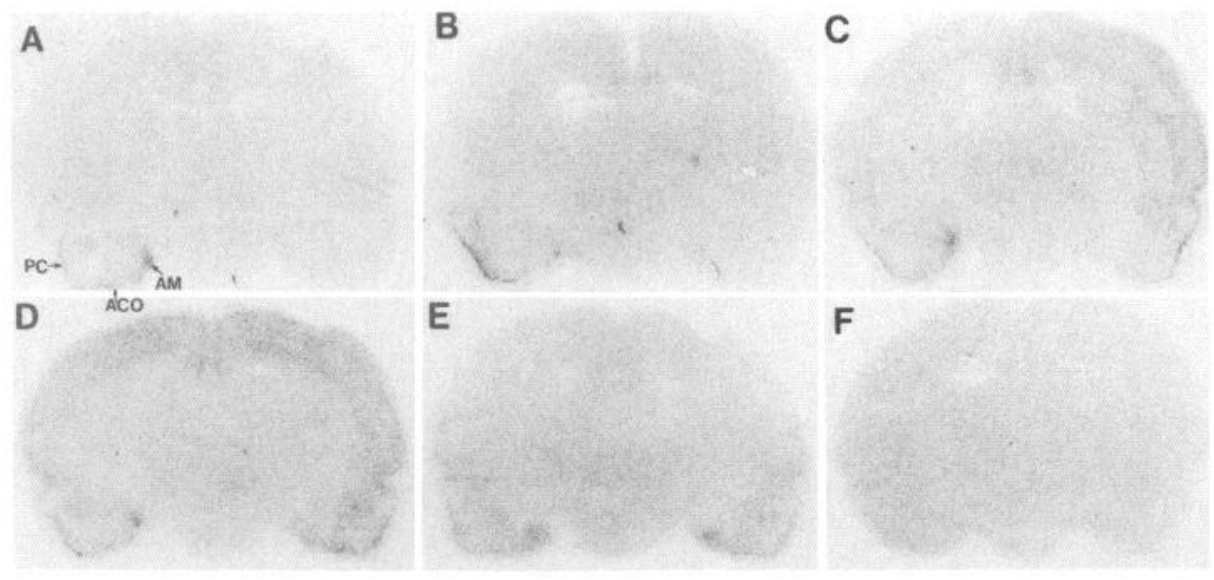

Figure 1. Amygdala stimulation: expression of c-fos mRNA at EPN level as a function of number of stimulations. Shown are autoradiograms of representative coronal brain sections at the level of the entopeduncular nucleus (EPN), exhibiting total hybridization of the ${ }^{32} \mathrm{P}-\mathrm{labeled} \mathrm{c}$-fos oligonucleotide probe in animals sacrificed $30 \mathrm{~min}$ after delivery of one stimulation (class 0 seizure; 29 sec amygdala ADD; $A$ ), three stimulations (class 0 seizure; $13 \mathrm{sec}$ ADD; $B$ ), five stimulations (class 4 seizure; $42 \mathrm{sec}$ ADD; $C$ ), seven stimulations (class 3 seizure; 81 sec ADD; $D$ ), or three class 5 seizures $(56 \mathrm{sec} \mathrm{ADD} ; E$ ). $F$ is a representative autoradiogram exhibiting homogeneous, nonspecific hybridization of the radiolabeled c-fos probe. The right side of each autoradiogram is oriented to the viewer's left. A few neuronal structures of particular interest are labeled in $A$ : $A M$, $A C O$, and $P C$. See Figure $6 D$ for a more complete guide to the neuronal structures analyzed at this level (Pellegrino and Cushman, 1967); labeled regions in Figure $6 D$ include amygdaloid nuclei. These "representative" sections will not fully correlate with the mean c-fos induction shown in Table 1 because of slight differences in IEG expression in the five animals of each group.

for $4 \mathrm{hr}$ at $37^{\circ} \mathrm{C}$ in solution containing $50 \%$ formamide (Bethesda $\mathrm{Re}-$ search Laboratories, Gaithersburg, MD), $2 \times$ NTE $(10 \times$ NTE $=3 \mathrm{M}$ $\mathrm{NaCl}, 100 \mathrm{~mm}$ Tris-HCl, $10 \mathrm{~mm}$ EDTA), $1 \times$ Denhardt's solution (Sig$\mathrm{ma}$, St. Louis, MO), $500 \mu \mathrm{g} / \mathrm{ml}$ yeast tRNA (Sigma), $500 \mu \mathrm{g} / \mathrm{ml}$ salmon sperm DNA (Sigma), and $0.05 \%$ sodium pyrophosphate (Sigma). Sections were hybridized for $16 \mathrm{hr}$ at $37^{\circ} \mathrm{C}$ in solution identical to that used for prehybridization with the following differences: $100 \mu \mathrm{g} / \mathrm{ml}$ DNA; $100 \mu \mathrm{g} / \mathrm{ml} \mathrm{tRNA}$; and the addition of $75,000 \mathrm{CPM} / \mu \mathrm{l}$ radiolabeled probe, either alone (total hybridization) or with 100-fold excess nonradiolabeled probe (nonspecific hybridization) in an adjacent section. Sections were then washed in $1 \times \mathrm{NTE}$ at $37^{\circ} \mathrm{C}$ for $3 \mathrm{hr}$ and dehydrated. We generated autoradiograms by apposing these dried sections alongside ${ }^{32} \mathrm{P}$ standards to Betamax film (Amersham, Arlington Heights, IL) at $-70^{\circ} \mathrm{C}$ for $72 \mathrm{hr}$ as described by Simonato et al. (1991).

Data analysis of autoradiograms. After development of the film, a digital image analysis system (Loats, Inc; supplied by Amersham) was used to obtain optical density measurements over structures of interest in the autoradiograms. In animals stimulated from the angular bundle, the following 22 structures were analyzed: nucleus accumbens, prepyriform cortex, caudate-putamen, entopeduncular nucleus, layers $2 / 3$ of frontal neocortex, layers $5 / 6$ of frontal neocortex, lateral and ventral thalamic nuclei, globus pallidus, pyriform cortex, amygdaloid subnuclei [basomedial (ABM), basolateral (ABL), posterolateral (APL), anterior cortical (ACO), central (AC), and medial (AM)], dentate gyrus stratum granulosum (DGC), stratum pyramidale of hippocampal areas CA3 (henceforth referred to as "CA3") and CA1 (henceforth referred to as "CA1"), substantia nigra, entorhinal cortex (EC), and medial geniculate nucleus. In animals stimulated from the amygdala, a subset of the structures analyzed in angular bundle-kindled animals were studied. These included pyriform cortex (PC), amygdaloid subnuclei (ABM, ABL, APL, ACO, and AM), DGC, CA3 and CA1. The amygdaloid nuclei were identified in the autoradiograms by comparing the relationships between them and easily detectible landmarks (e.g., optic tract, internal capsule), as described by Krettek and Price, (1978a,b), and by using brain atlases. The other structures were clearly recognized by comparing the autoradiograms to brain atlases (Pellegrino and Cushman, 1967).

Specific hybridization was defined as the difference in total and nonspecific optical density. Specific optical density measurements for each population were compared with those obtained from the ${ }^{32} \mathrm{P}$ standards to convert OD units into units of moles $\times 10^{-20} / \mathrm{mm}^{2}$. The assumption used to make this conversion was that each mole of probe was radiolabeled with $6 \mathrm{~mol}$ of ${ }^{32} \mathrm{P}$-dATP. This assumption was based upon the molar ratio of nonradiolabeled probe to ${ }^{32} \mathrm{P}-\mathrm{dATP}$ in the reaction catalyzed by terminal transferase; initial experiments confirmed that the reaction proceeded to completion and yielded radiolabeled probe of the expected specific activity in every case. By using this method of standardization, small differences in OD resulting from differences in film development were corrected, allowing values obtained from homologous regions to be compared across different films. Assuming that the radiolabeled probe had equal access to its complementary mRNA in every regional structure, the final values (units in moles $\times 10^{-20} / \mathrm{mm}^{2}$ ) afforded the best estimates of the mRNA actually present. These final values for each neuronal structure were compared to visual inspection of the structure on the original autoradiograms, to ensure that measured values corresponded to visually detectable expression.

The mean specific expression of each IEG within a particular neuronal population was then computed and compared across other neuronal structures within each group of animals, using analysis of variance (Snedecor and Cochran, 1980). In groups showing significant acrossstructure variances $(p<0.05)$, a post hoc test was used to determine those populations in which induction of expression was significantly greater $(p<0.05)$ than in corresponding populations from control animals. In amygdaloid-kindled groups, a least squares of differences (LSD) test was used; for angular bundle-kindled animals, a KruskalWallis test was used (Snedecor and Cochran, 1980).

Histologic verification of electrode placement. Placement of the amygdala stimulating electrode in each animal was verified by examining sections showing the ventralmost extent of the electrode track. These sections were stained with cresyl violet and analyzed with reference to anatomic descriptions of amygdaloid nuclei (Krettek and Price, 1978a,b). Examination of brain sections from amygdala-kindled animals revealed placement of the stimulating electrode into $\mathrm{ABM}$ in $60 \%(n=24), \mathrm{ABL}$ in $16 \%$, AM in $8 \%$, APL in $16 \%$, and AC in $8 \%$. We found no correlation between the sites of amygdaloid electrode placement and the IEG expression within that group of animals. Thus, the electrode placement within the amygdaloid subnuclei did not appear to affect the anatomic pattern of induction of these IEGs.

Placement of the angular bundle stimulating electrodes was verified electrophysiologically during surgery (Shin, 1987), obviating the need for histologic verification following experiments.

\section{Results}

Amygdala kindling: development from single AD to class 5 kindled seizure

Significant $(p<0.05)$ induction of $c$-fos mRNA expression was determined by comparing stimulated to sham-stimulated (constitutive) c-fos expression. After a single $\mathrm{AD}$, significant c-fos mRNA induction occurred primarily in the ipsilateral ACO and 

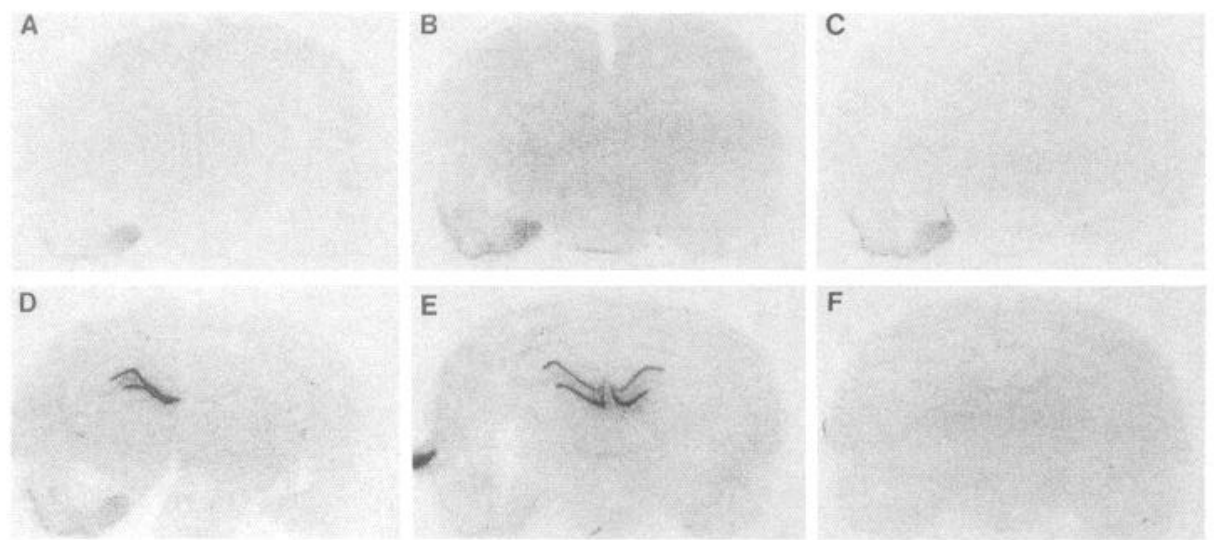

Figure 2. Amygdala stimulation: expression of c-fos mRNA at hippocampal level as a function of number of stimulations. Shown are representative autoradiograms of brain sections at the level of the dorsal hippocampus, exhibiting total hybridization of the ${ }^{32} \mathrm{P}$-labeled $\mathrm{c}$-fos oligonucleotide probe in animals sacrificed $30 \mathrm{~min}$ after delivery of one stimulation (class 0 seizure; $29 \mathrm{sec}$ amygdala ADD; $A$ ), three stimulations (class 0 seizure; 13 sec ADD; $B$ ), five stimulations (class 1 seizure; $43 \mathrm{sec}$ ADD; $C$ ), seven stimulations (class 3 seizure; 29 sec ADD; $D$ ), or three class 5 seizures $(86 \mathrm{sec} \mathrm{ADD} ; E) . F$ exhibits nonspecific hybridization of the radiolabeled $\mathrm{c}$-fos probe. The right side of each autoradiogram is oriented to the viewer's left; portions of the track produced by the stimulating electrode are visible in or near the right amygdaloid complex in most sections. See Figure $6 G$ for a guide to the neuronal structures analyzed at the corresponding hippocampal level (Pellegrino and Cushman, 1967); labeled regions in Figure $6 G$ include DGC, hippocampal areas CA3 and CA1, and pyriform cortex (P).

AM subnuclei and in PC (Table 1; Figs. 1, 2). During the course of kindling development, a progressive evolution of populations exhibiting c-fos mRNA expression was observed. This evolution in the anatomic distribution of c-fos mRNA expression occurred first in ACO and AM, and then in DGC, CA3, and CA1 (Table 1). However, c-fos mRNA was expressed in DGC in only two of five animals even after class 5 seizures, despite prolonged ADD recorded with a bipolar hippocampal electrode in all of these animals. Induction did not occur in other amygdaloid nuclei but did occur to a variable extent in neocortex and dorsal endopyriform nucleus.

NGFI-A mRNA expression was exquisitely sensitive to seizure-induction. A modest constitutive level of NGFI-A mRNA expression was found in unstimulated control animals (Figs. 3A, $4 A)$. Significant $(p<0.05)$ induction of NGFI-A mRNA was observed in many of the same neuronal populations that ex- pressed c-fos mRNA: AM, ACO, PC, DGC, CA3, and CA1; no induction was observed in other amygdaloid nuclei (Table 2; Figs. 3, 4). However, in contrast to the predominantly ipsilateral expression of c-fos mRNA following a single $\mathrm{AD}$, NGFI-A mRNA expression was prominent bilaterally in $\mathrm{AM}, \mathrm{ACO}$, and $\mathrm{PC}$ after a single $\mathrm{AD}$ (Table 2). Surprisingly, the expression of NGFI-A in bilateral AM, ACO and PC increased in intensity between one and seven ADs and then decreased between seven ADs and three class 5 seizures. Consequently, the NGFI-A expression in these structures after a single $\mathrm{AD}$ was greater than the expression after three class 5 seizures. In DGC, however, the magnitude of expression was greater after class 5 seizures than after a single AD. Hence, a quantitative evolution of NGFI-A expression occurred only in DGC.

NGFI-B expression was both less frequently and less robustly induced than was the expression of c-fos or NGFI-A mRNAs
Figure 3. Amygdala stimulation: expression of NGFI-A mRNA at EPN level as a function of number of stimulations. Shown are autoradiograms of coronal sections at the level of the EPN, exhibiting total hybridization of radiolabeled NGFI-A probe in animals sacrificed $30 \mathrm{~min}$ after one stimulation (class 0 seizure; $18 \mathrm{sec}$ ADD; $B$ ), three stimulations (class 0 seizure; $13 \mathrm{sec}$ $\mathrm{ADD} ; C$ ), five stimulations (class 2 seizure; 43 sec ADD; $D$ ), seven stimulations (class 3 seizure; $81 \mathrm{sec}$ ADD; $E$ ), or three class 5 seizures (56 sec ADD; $F$ ). The moderate amount of constitutive expression of NGFI-A mRNA in an implanted, unstimulated control animal is shown in $A$; nonspecific hybridization is shown in $G$. Some of the neuronal structures in these "representative" sections may not correspond precisely with the mean values in Table 2 , due to slight animal-to-animal variability in IEG expression in the group.



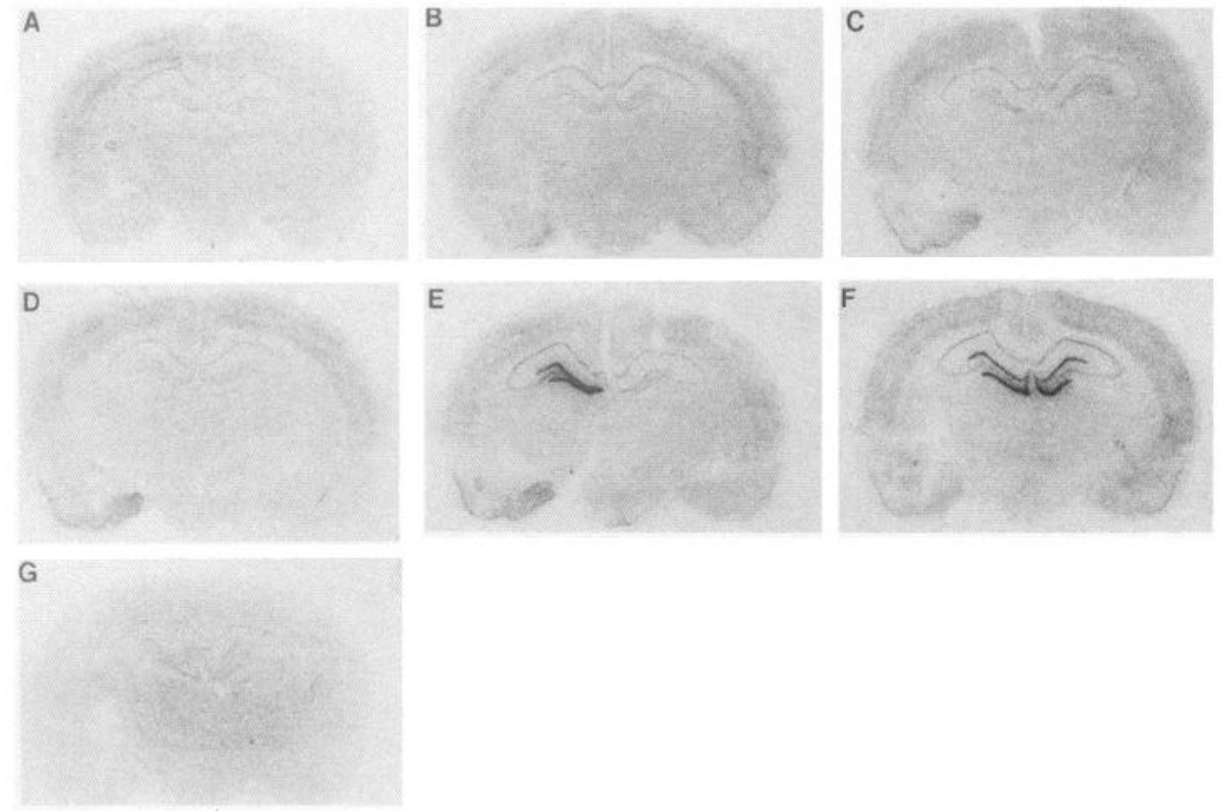

Figure 4. Amygdala stimulation: expression of NGFI-A mRNA at hippocampal level as a function of number of stimulations. Shown are autoradiograms of coronal sections at the level of the dorsal hippocampus, exhibiting total hybridization of radiolabeled NGFI-A probe in animals sacrificed 30 min after one stimulation (class 0 seizure; $29 \mathrm{sec}$ ADD; $B$ ), three stimulations (class 2 seizure; $116 \mathrm{sec}$ ADD; $C$ ), five stimulations (class 0 seizure; $24 \sec \mathrm{ADD} ; D$ ), seven stimulations (class 5 seizure; 81 sec ADD; $E$ ), or three class 5 seizures ( $86 \mathrm{sec}$ ADD; $F$ ). The moderate amount of constitutive expression of NGFI-A mRNA in an implanted, unstimulated control animal is shown in $A$; nonspecific hybridization is shown in $G$.

Table 2. Amygdala stimulation: mean induction of NGFI-A mRNA as a function of seizure class and afterdischarge duration

\begin{tabular}{lllllll} 
& \multicolumn{7}{c}{ Number of stimulations } & \\
\cline { 2 - 5 } & & 1 & 3 & 5 & 7 & Three class \\
5 seizures
\end{tabular}

Shown is the mean expression of NGFI-A mRNA (moles $\times 10^{-20} / \mathrm{mm}^{2}$ ) in nine neuronal populations (abbreviations same as in Fig. 6) as a function of the number of stimulations. These mean values may not correspond precisely to figures because of animal-to-animal variability. Mean seizure class and mean amygdala and hippocampal afterdischarge durations (ADD) are shown for each group of animals. Mean constitutive expression of NGFI-A mRNA within each structure is shown in parentheses in the left column.
Table 3. Amygdala stimulation: mean induction of NGFI-B mRNA as a function of seizure class and afterdischarge duration

\begin{tabular}{|c|c|c|c|c|c|c|}
\hline & \multicolumn{4}{|c|}{ Number of stimulations } & \multirow{2}{*}{$\begin{array}{l}\text { Three class } \\
5 \text { seizures }\end{array}$} \\
\hline & & 1 & 3 & 5 & 7 & \\
\hline \multirow{2}{*}{\multicolumn{2}{|c|}{$\begin{array}{l}\text { Seizure class } \\
\text { Amygdala ADD } \\
(\mathrm{sec})\end{array}$}} & 0 & 0.5 & 2.3 & 2.4 & 5 \\
\hline & & 19.6 & 34.0 & 45.6 & 62.8 & 63.4 \\
\hline \multicolumn{7}{|c|}{ Hippocampal } \\
\hline \multicolumn{2}{|c|}{ ADD (sec) } & 3.3 & 34.0 & 45.6 & 62.8 & 63.4 \\
\hline \multirow[t]{2}{*}{$\mathrm{ACO}$} & $\mathrm{R}$ & 0 & 0 & 0 & 0 & 0 \\
\hline & $\mathrm{L}$ & 0 & 0 & 0 & 0 & 0 \\
\hline \multirow[t]{2}{*}{$\mathrm{AM}$} & $\mathrm{R}$ & 0 & 0 & 0 & 0 & 0 \\
\hline & $\mathrm{L}$ & 0 & 0 & 0 & 0 & 0 \\
\hline \multirow[t]{2}{*}{$\mathrm{ABM}$} & $\mathrm{R}$ & 0 & 0 & 0 & 0 & 0 \\
\hline & L & 0 & 0 & 0 & 0 & 0 \\
\hline \multirow[t]{2}{*}{$\mathrm{ABL}$} & $\mathrm{R}$ & 0 & 0 & 0 & 0 & 0 \\
\hline & L & 0 & 0 & 0 & 0 & 0 \\
\hline \multirow[t]{2}{*}{ APL } & $\mathrm{R}$ & 0 & 0 & 0 & 0 & 0 \\
\hline & $\mathrm{L}$ & 0 & 0 & 0 & 0 & 0 \\
\hline \multirow[t]{2}{*}{ PC } & $\mathrm{R}$ & 0 & 0 & 0 & 0.8 & 0 \\
\hline & $\mathrm{L}$ & 0 & 0 & 0.4 & 0.3 & 0.3 \\
\hline \multirow[t]{2}{*}{ DGC } & $\mathrm{R}$ & 0 & 0 & 1.1 & 2.1 & 1.2 \\
\hline & L & 0 & 0 & 1.1 & 0.6 & 1.3 \\
\hline \multirow[t]{2}{*}{$\mathrm{CA} 3$} & $\mathrm{R}$ & 0.1 & 0 & 0 & 0.2 & 0.3 \\
\hline & $\mathrm{L}$ & 0.1 & 0 & 0 & 0.2 & 0.4 \\
\hline \multirow[t]{2}{*}{ CA1 } & $\mathrm{R}$ & 0.1 & 0 & 0 & 0.2 & 0.3 \\
\hline & $\mathrm{L}$ & 0.1 & 0 & 0 & 0.2 & 0.3 \\
\hline
\end{tabular}

Shown is the mean expression of NGFI-B mRNA $\left(\right.$ moles $\left.\times 10^{-20} / \mathrm{mm}^{2}\right)$ in nine neuronal populations (abbreviations same as in Fig. 6) as a function of the number of stimulations. These mean values may not correspond precisely to figures because of animal-to-animal variability. Mean seizure class and mean amygdala and hippocampal afterdischarge durations (ADD) are shown for each group of animals. There was no detectable constitutive expression of NGFI-B mRNA in any of these structures. 
Figure 5. Amygdala stimulation: comparison of c-fos, NGFI-A, and NGFI-B expression after five stimulations. Shown are autoradiograms of coronal sections at the level of the dorsal hippocampus from an animal sacrificed $30 \mathrm{~min}$ after the fifth stimulation, which produced a class 4 seizure. Note the modest expression of NGFI-B mRNA in DGC ( $A$, total; $B$, nonspecific), in contrast to a more marked expression of c-fos mRNA $(C)$ and a robust expression of NGFI-A mRNA $(D)$ in the same animal.
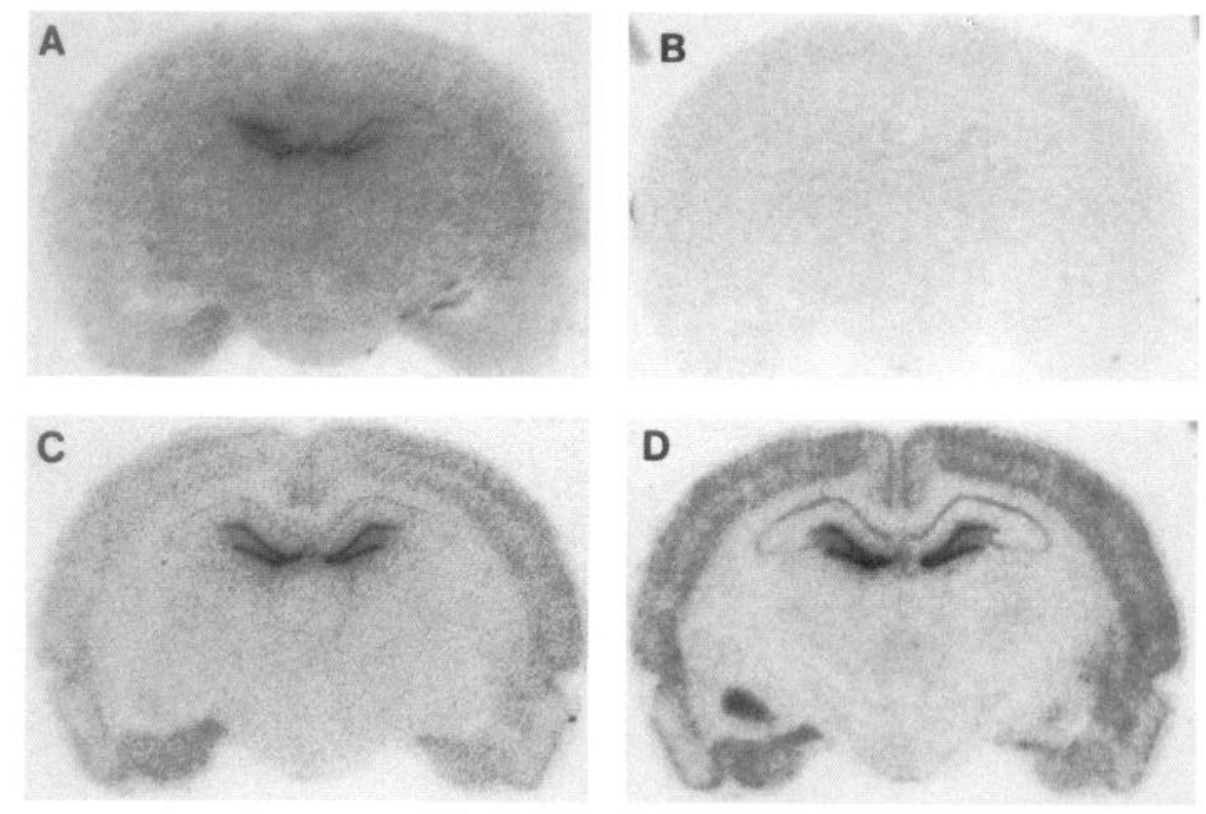

(Table 3). Even after three class 5 seizures, induction was limited primarily to PC, although a modest expression of NGFI-B was also observed in PC, CA3 and CA1. Moreover, even when significant induction of NGFI-B mRNA was observed (Fig. 5A), its induction was less robust and less widespread than that for c-fos (Fig. 5C) or NGFI-A (Fig. 5D) within brain sections from the same animal.

\section{Angular bundle kindling: single AD versus class 5 kindled seizure}

Compared to controls, significant and robust induction of c-fos mRNA expression occurred bilaterally in 4 of 22 neuronal populations after a single $\mathrm{AD}$ : DGC, stratum pyramidale of hippocampal areas CA3 and CA1, and PC (Fig. 6). There was no significant induction of c-fos mRNA expression in the other 18 structures, including AM, ACO, and other amygdaloid nuclei.

Importantly, a similar anatomic distribution was present after three class 5 seizures (Fig. 6, Table 4). Thus, robust induction of c-fos mRNA was measured in DGC, CA3, CA1, and PC. There were no additional neuronal populations in which c-fos mRNA was induced, comparing the effect of a single AD to that of a class 5 kindled seizure (Table 4). Stated differently, there was no apparent evolution in the anatomic distribution of c-fos mRNA during kindling development from the angular bundle, in contrast to the evolution in expression of this IEG after amygdaloid kindling.

The anatomic distribution of c-jun mRNA differed from that for c-fos. Following a single $\mathrm{AD}$, significant induction of c-jun mRNA was detected only in DGC bilaterally (Fig. 7E). Likewise, significant induction of c-jun mRNA was observed solely in DGC following three class 5 seizures (Fig. 7, Table 4). None of the remaining 21 populations exhibited c-jun mRNA expression after either a single AD or a class 5 seizure. There was no significant difference in the expression of c-jun mRNA within the DGC in animals with a single $\mathrm{AD}$, compared to animals with a kindled seizure (Table 4).

The anatomic distribution of NGFI-A mRNA differed from that of both c-fos and c-jun in two ways. First, NGFI-A mRNA was constitutively expressed in PC, DGC, and neocortex in con- trol animals. Second, significant induction of NGFI-A mRNA was detected in DGC and entorhinal cortex but in none of the remaining 20 populations following a single AD (Fig. 8). Although NGFI-A mRNA was induced to a slightly greater extent in these populations following three class 5 seizures (Fig. 8, Table 4), there was no significant difference in NGFI-A mRNA within DGC or entorhinal cortex between animals with a single $\mathrm{AD}$ and those with kindled seizures (Table 4).

\section{Angular bundle kindling: alternate parameters for final stimulation}

The above results were obtained from animals in which the angular bundle was stimulated once daily until the penultimate seizure; the final seizure was induced $1 \mathrm{~d}$ after the penultimate one and animals were sacrificed $15 \mathrm{~min}$ later (see Materials and Methods, second group). In contrast, results from amygdaloid kindling were obtained from animals in which the final seizure was induced $7 \mathrm{~d}$ after the penultimate one, and animals were sacrificed $30 \mathrm{~min}$ later. To provide a more valid comparison between animals kindled from these two sites, an additional group of animals (see Materials and Methods, third group) was kindled from the angular bundle, using stimulation parameters similar to those of the amygdala-kindled group. Thus, the final seizure was induced $7 \mathrm{~d}$ after the penultimate one, and animals were sacrificed $30 \mathrm{~min}$ later. Importantly, the pattern of c-fos expression was equivalent to the group sacrificed $15 \mathrm{~min}$ after the last seizure; in particular, the animals in this group did not have any c-fos expression in amygdaloid nuclei, a result distinct from that obtained in amygdaloid kindled animals (results not shown).

\section{Constitutive expression of IEG MRNAs 28 d after angular bundle-kindled seizure}

In animals sacrificed $28 \mathrm{~d}$ after the last class 5 seizure (see Materials and Methods, fourth group), no structures exhibited significant induction of c-fos, c-jun, or NGFI-A mRNAs, compared to implanted but unstimulated controls. Thus, there was no change in constitutive IEG expression in kindled compared to naive animals. 

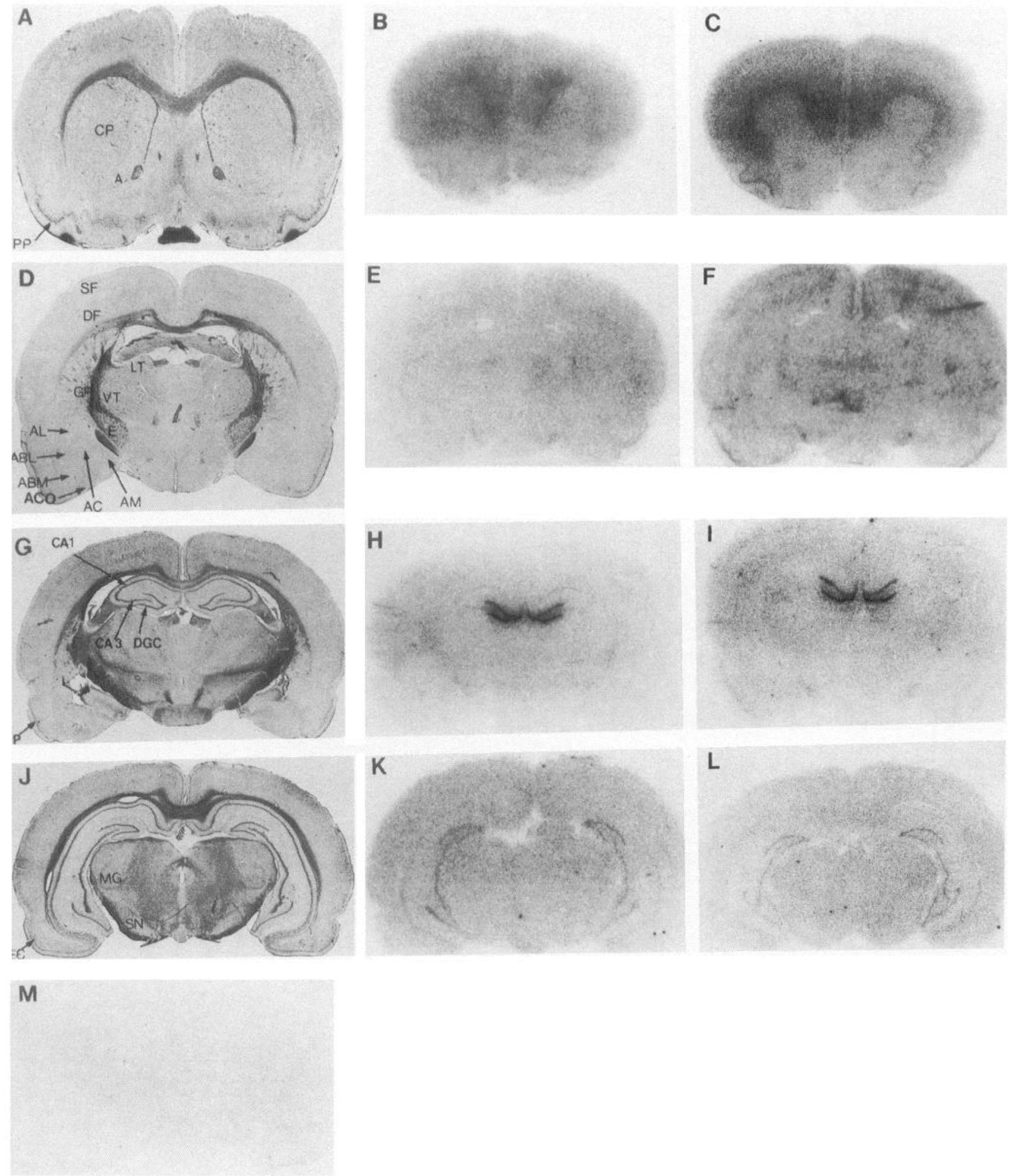

Figure 6. Angular bundle stimulation: c-fos mRNA expression after single AD and three class 5 seizures. The structures analyzed at each of four levels are shown in the Nissl-stained section for that level. $A-C$, Accumbens level: Nissl $(A)$, single AD $(B)$, class 5 seizure $(C)$. $C P$, caudateputamen; $A$, nucleus accumbens; $P P$, prepyriform cortex. $D-F$, Entopeduncular nucleus level: Nissl $(D)$, single AD $(E)$, class 5 seizure $(F)$. $S F$, layers $2 / 3$ of frontal neocortex; $D F$, layers $5 / 6$ of frontal neocortex; $L T$, lateral thalamic nucleus; $V T$, ventral thalamic nucleus; $G P$, globus pallidus; $E$, entopeduncular nucleus; $A L$, lateral amygdaloid nucleus; $A B L$, basolateral amygdaloid nucleus; $A B M$, basomedial amygdaloid nucleus; $A C$, central amygdaloid nucleus; $A C O$, cortical amygdaloid nucleus; $A M$, medial amygdaloid nucleus. $G-I$, Dorsal hippocampus level: Nissl $(G)$, single $\mathrm{AD}(H)$, class 5 seizure $(I) . D G C$, dentate gyrus stratum granulosum; $C A 1$, stratum pyramidale in hippocampal area CA1; $C A 3$, stratum pyramidale in hippocampal area CA $3 ; P$, pyriform cortex. $J-L$, Substantia nigra level: Nissl $(J)$, single AD $(K)$, class 5 seizure $(L)$. $M G$, medial geniculate; $S N$, substantia nigra; $E C$, entorhinal cortex. $M$ represents nonspecific hybridization. The sections were hybridized with ${ }^{32} \mathrm{P}$-labeled oligonucleotide probe to c-fos mRNA, alone (total hybridization: $A-L$ ) or in the presence of 100 -fold unlabeled probe (nonspecific hybridization: $M$ ). 
Table 4. Angular bundle stimulation: neuronal populations with significant induction of IEG expression

\begin{tabular}{lllll} 
IEG & Structure & & $\begin{array}{l}\text { One } \\
\text { stimulation }\end{array}$ & $\begin{array}{l}\text { Class 5 } \\
\text { seizure }\end{array}$ \\
\hline c-fos & \multirow{2}{*}{ DGC } & R & 1.4 & 1.6 \\
& & L & 1.4 & 1.6 \\
& CA3 & R & 0.4 & 1.0 \\
& & L & 0.4 & 0.8 \\
& CA1 & R & 0.4 & 1.0 \\
& & L & 0.4 & 0.8 \\
& PC & R & 0.6 & 1.0 \\
& & L & 0.4 & 0.6 \\
c-jun & DGC & R & 1.0 & 1.0 \\
& & L & 1.2 & 1.0 \\
NGFI-A & DGC & R & 0.8 & 0.8 \\
& & L & 1.0 & 1.0 \\
& EC & R & 1.0 & 1.4 \\
& & L & 1.0 & 1.4
\end{tabular}

Twenty-two structures were analyzed (see Materials and Methods). The structures shown are the only ones in which IEG expression was significantly induced $15 \mathrm{~min}$ after a class 5 kindled seizure compared to control animals. Values are in units of (moles $\left.\times 10^{-20} / \mathrm{mm}^{2}\right)$. The means shown here may not correspond precisely to figures because of animal-to-animal variability in IEG expression. Statistical significance was determined by a Kruskal-Wallis post hoc test $(p<0.05)$ after significant $(p<0.05)$ differences were found across all structures with an ANOVA. When IEG expression in these structures following a class 5 kindled seizure was compared to that following a single AD, no significant differences were found.

\section{Discussion}

Six principal findings emerge from this work. (1) Generalized limbic and clonic motor (class 5) kindled seizures evoked by stimulation of one amygdala induced the expression of IEGs in a small subset of limbic structures with remarkable symmetry between the two hemispheres. (2) The anatomic extent of seizure-evoked expression of c-fos mRNA expanded progressively following focal limbic and motor (classes 0-3) seizures during the development of amygdala kindling; c-fos mRNA was detected first ipsilaterally in AM, ACO, and PC and with higherclass seizures in hippocampal formation and homologous structures contralaterally. (3) IEGs exhibited different sensitivities of seizure-induced expression with a rank order of thresholds (most sensitive to least sensitive) of NGFI-A $>$ c-fos $>$ c-jun $>$ NGFIB. (4) Despite the different sensitivities, expression of all of the IEGs was induced in the same constellation (or a subset thereof) of anatomic structures. (5) Class 5 seizures evoked by stimulation of two different sites in the limbic system (amygdala or angular bundle) induced IEG expression in distinct but partially overlapping anatomic structures. (6) There was no change in the constitutive level of IEG expression in animals sacrificed $28 \mathrm{~d}$ after the last class 5 seizure.

The fact that a small subset of nuclei exhibited IEG expression following a generalized limbic and clonic motor seizure was unexpected in view of the widespread propagation of seizure activity. Seizure activity is evident in a vast number of forebrain and brainstem structures during class 5 seizures as detected by 2-deoxyglucose autoradiography (Engel et al., 1978) or in recording of EEG activity from intracerebral electrodes (Mars and Lopes da Silva, 1983; McNamara et al., 1985). These structures include hippocampal and amygdaloid nuclei in which IEG expression was observed in this study. These structures also include many thalamic, basal ganglia, and brainstem nuclei, in
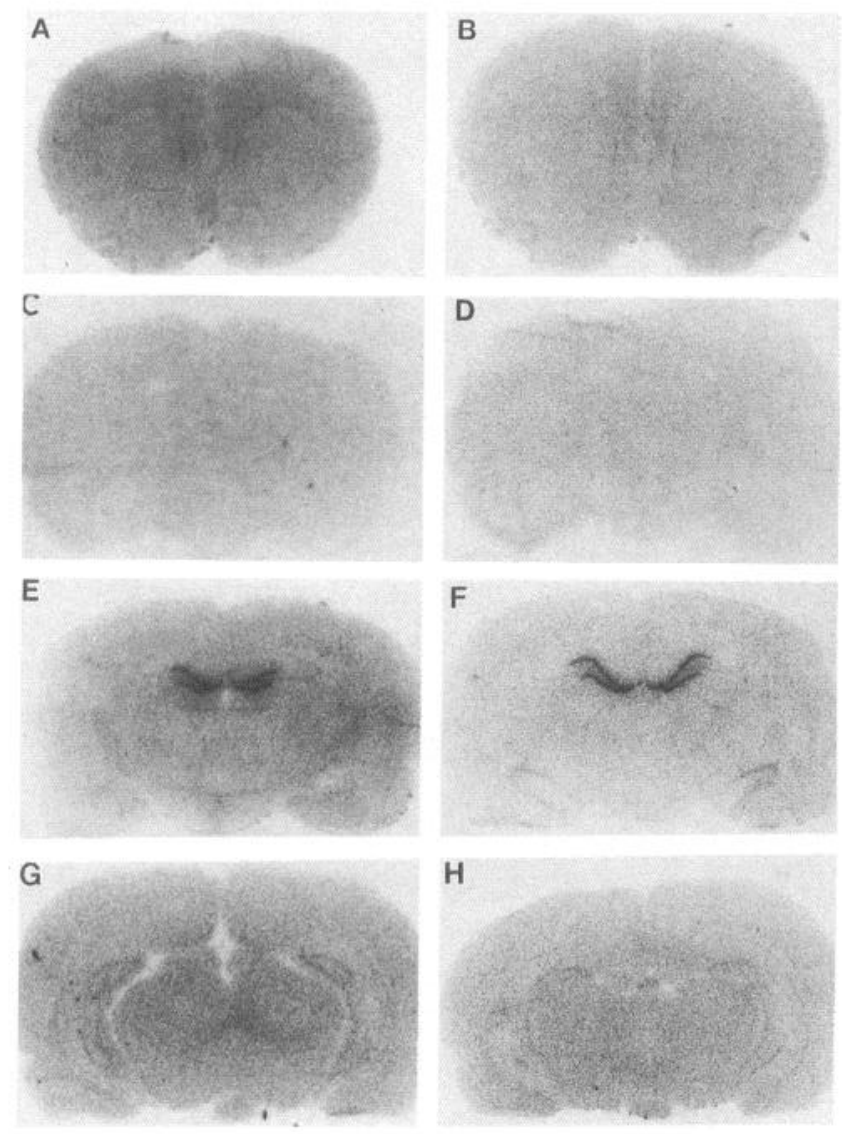

I

Figure 7. Angular bundle stimulation: c-jun mRNA expression after single $\mathrm{AD}$ and three class 5 seizures. The structures analyzed at each level are similar to those shown in Figure 6; rows are arranged in a manner similar to those in Figure 6. $A, C, E$, and $G$ (left side) represent total hybridization after a single $\mathrm{AD} ; B, D, F$, and $H$ (right side) represent total hybridization after a class 5 kindled seizure. $I$ represents nonspecific hybridization. The sections were hybridized with ${ }^{32} \mathrm{P}$-labeled oligonucleotide probe to c-jun mRNA, in the absence (total hybridization) or presence of 100-fold unlabeled probe (nonspecific hybridization).

which IEG expression was not observed in this study. Another unexpected finding was that kindled seizures evoke the expression of multiple IEGs in a single subset of anatomic structures. The number of potential combinations of structures in which IEG expression might have been induced is vast. However, each IEG is expressed in a subset of the constellation of structures in which the most sensitive IEG, NGFI-A, is induced. This implies some commonality in the mechanism by which a seizure evokes expression of the various IEGs. Yet the different sensitivities among the various IEGs (NGFI-A >c-fos $>$ c-jun $>$ NGFI-B) to seizure-evoked expression also imply some differences in the mechanisms.

The restricted distribution of IEG expression following a kindled seizure underscores the fact that epileptiform burst-firing of 

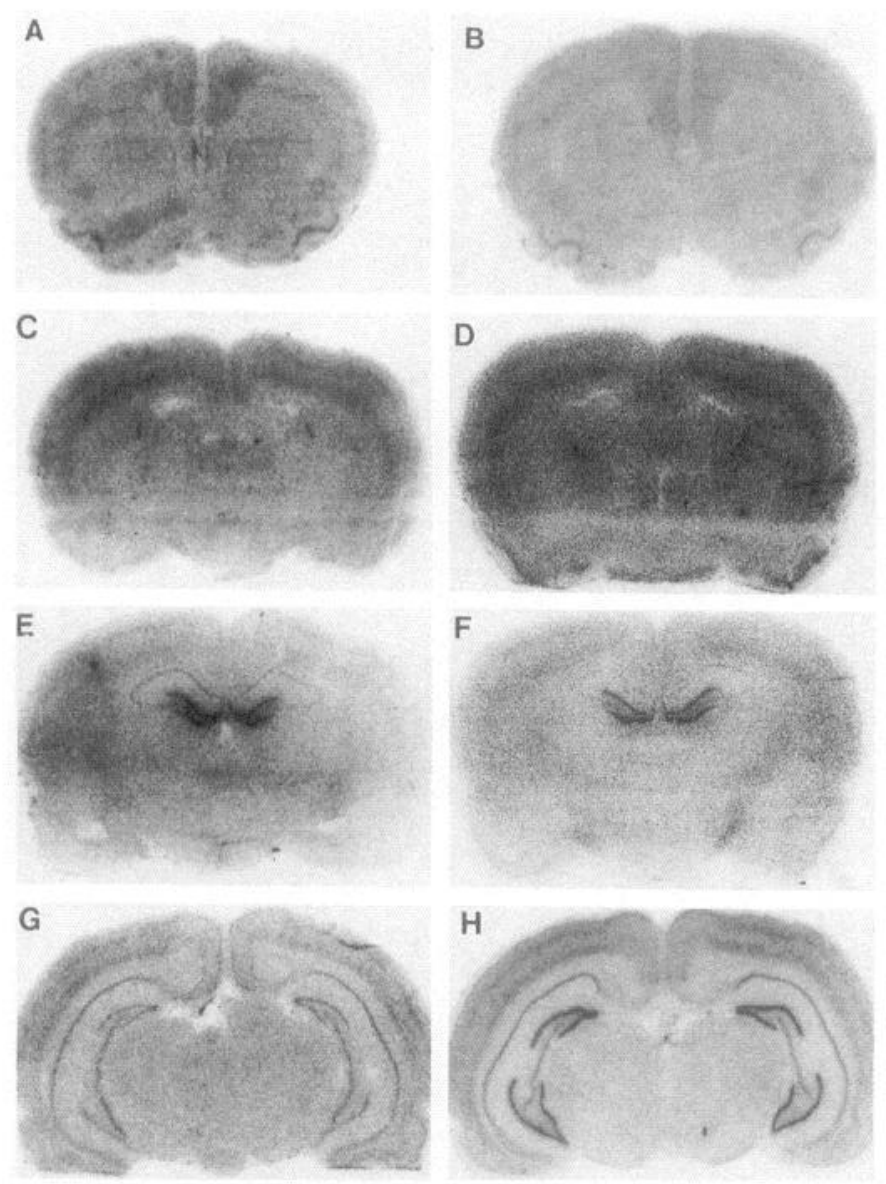

1

Figure 8. Angular bundle stimulation: NGFI-A mRNA expression after single AD and three class 5 seizures. The structures analyzed at each level are similar to those shown in Figure 6. Panels are arranged identically to those of Figure 7 . The sections were hybridized with ${ }^{32} \mathrm{P}-$ labeled oligonucleotide probe to NGFI-A mRNA, in the absence (total hybridization) or presence of 100 -fold unlabeled probe (nonspecific hybridization).

neurons is not sufficient to explain the seizure-evoked IEG expression. This has been demonstrated by the absence of c-fos expression in pars reticulata of substantia nigra (Labiner et al., 1993) following a kindled seizure. Unit recordings of pars reticulata neurons of substantia nigra during a class 5 kindled seizure demonstrate burst-firing (Bonhaus et al., 1986; Bonhaus et al., 1991) yet no evidence of seizure-evoked IEG expression was detected here or in our previous work (Labiner et al., 1993).

One possibility explaining the restriction of IEG expression to this select subset of nuclei is that neurons in these nuclei undergo activation of glutamate receptors with a resultant rise of $\mathrm{Ca}_{i}$ during the seizure. This proposal is based upon both in vivo and in vitro studies of mechanisms of IEG expression in dentate granule cells. In vivo studies demonstrate that activation of the NMDA subtype of glutamate receptor is necessary for
A. POSITIVE EXPRESSION: IPSILATERAL STRUCTURES



\section{B. POSITIVE EXPRESSION: CONTRALATERAL STRUCTURES}

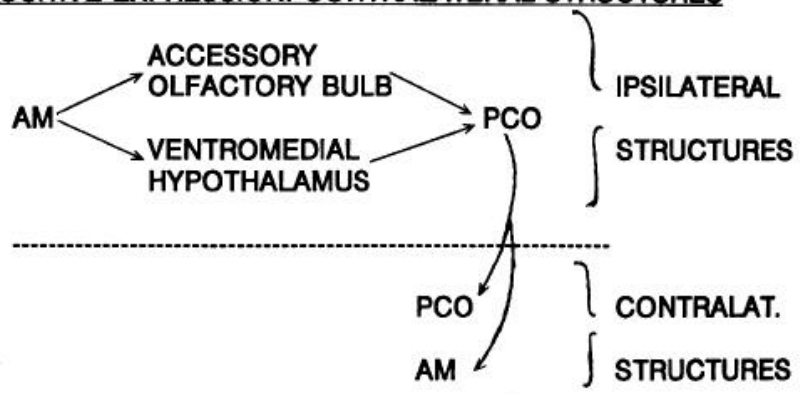

Figure 9. Anatomic networks that may underlie the patterns of IEG expression in amygdaloid kindled animals. Anatomic networks are diagrammed for conditions in which amygdaloid kindling: $A$ yielded ipsilateral IEG expression in ACO and PC; $B$ yielded contralateral expression in posterior cortical amygdaloid nucleus (PCO) and AM.

the full expression of c-fos mRNA, since NMDA receptor antagonists markedly reduce $\mathrm{c}-$ fos expression without reducing the firing of these neurons during class 5 seizures (Labiner et al., 1993). In vitro studies demonstrate that activation of NMDA receptors is sufficient to induce expression of c-fos, c-jun, and NGFI-A in a Ca ${ }^{2+}$-requiring manner (Lerea et al., 1992; Lerea and McNamara, 1993a). We hypothesize that mechanisms controlling c-fos mRNA expression in dentate granule cells during class 5 seizures are operative in neurons in the diverse structures observed here. The similarity in distribution of these IEGs may stem from synaptic activation of NMDA and other glutamate receptors in these diverse neuronal populations during the seizure. The different sensitivities in the expression of the various IEGs following a seizure may be due in part to the divergence of the signal transduction pathways activated by the rise of $\mathrm{Ca}_{i}$ (Lerea and McNamara, 1993a,b). Importantly, NMDA and AMPA receptors are present in all nuclei in which IEG expression is induced but also in many of the nuclei in which IEG expression is not induced following a seizure (Monaghan and Cotman, 1985; Maragos et al., 1988; Okazaki et al., 1990). Whether the subset of nuclei in which IEG expression is induced by kindled seizures undergoes preferential synaptic activation of glutamate receptors and/or exhibits different $\mathrm{Ca}_{i}$ buffering capacities is uncertain.

Our hypothesis predicts that synaptic activation of glutamate receptors contributes to the extraordinary specificity of structures expressing c-fos and other IEGs following amygdala stimulation. The anatomic distribution of c-fos IEG mRNA during early phases of amygdaloid kindling was confined mainly to amygdaloid nuclei (AM and ACO) ipsilateral to the stimulation, and then evolved into more widespread yet symmetrically distributed regions as kindling development proceeded. As one possible explanation, we propose that current spread from the stimulating electrode directly depolarized neurons within AM and initiated epileptiform burst firing associated with glutamate receptor activation in $\mathrm{AM}$ and synaptically related structures (Fig. 9). We further propose that this accounts for the uniform expression of c-fos within AM and within a subset of its synaptic 
targets. The proximity of the stimulating electrode to AM (always within $1 \mathrm{~mm}$ in histologic analyses) is consistent with the idea that neurons within AM were directly depolarized by current spread from the stimulating electrode. The kindling stimulations used in our study allow current to spread at least $1 \mathrm{~mm}$ (Ranck, 1975), a distance sufficient to depolarize AM neurons.

The polysynaptic anatomic connections between AM and ipsilateral ACO and PC neurons (Swanson, 1976; Krettek and Price, 1978a,b; Price et al., 1987) may have promoted synaptic activation of glutamate receptors of those neurons, thereby producing the IEG expression that we observed (see Fig. 9). Likewise, the striking symmetry of the subset of amygdaloid nuclei exhibiting c-fos expression in the amygdala contralateral to the stimulated site can be explained by other polysynaptic connections between AM and these structures (Swanson, 1976; DeOlmos et al., 1978; Krettek and Price, 1978b; Ottersen, 1982; Price et al., 1987). Finally, synaptic connections to entorhinal cortex may explain the propagation into hippocampal structures (Witter and Amaral, 1991; Amaral, 1993). With respect to the anatomic pattern of IEG expression evoked by angular bundle stimulation, the known anatomic connections within the hippocampal formation (Cotman and Nadler, 1978; Ottersen, 1982; Swanson et al., 1987; Amaral, 1993) appear to provide a network in which synaptic activation of glutamate receptors could produce the observed pattern of IEG expression.

The occurrence of IEG expression identifies a discrete subset of nuclei in which to pursue the structural and functional consequences of seizure-evoked IEG expression in the kindling model. Two lines of evidence suggest that some of these structural and functional consequences are causally related to formation of hyperexcitability. First, the link to NMDA receptor activation as one mechanism underlying seizure-evoked expression (Labiner et al., 1993) provides circumstantial evidence for a causal role, because NMDA receptor antagonists markedly inhibit kindling development (McNamara et al., 1988). Second, the impairment of kindling development identified in transgenic mice carrying a null mutation of $\mathrm{c}$-fos provides direct evidence for this assertion (Watanabe et al., 1994). Interestingly, hyperexcitability intrinsic to neurons and/or synapses has been identified in slices isolated from kindled animals in four neuronal populations exhibiting IEG expression after amygdala stimulation; these include the pyriform cortex, dentate granule cells, CA3 and CA1 pyramidal cells (King et al., 1985; McIntyre and Wong, 1986; Mody and Heinemann, 1987; Martin et al., 1992). Whether additional neuronal populations such as the medial or cortical amygdaloid nuclei also exhibit increased excitability remains to be determined.

The distinct but overlapping patterns of nuclei exhibiting IEG expression following stimulation of the amygdala and angular bundle may provide a clue to anatomic structures containing the hyperexcitability responsible for "transfer" (Goddard et al., 1969; Cain and Corcoran, 1981; Duchowny and Burchfiel, 1981; McNamara et al., 1985). Transfer refers to a phenomenon in which establishment of kindling by stimulation of one neuronal structure (e.g., an amygdaloid nucleus) results in fewer stimulations required for establishment of kindling by stimulation of a second structure (e.g., entorhinal cortex). The transfer phenomenon suggests that key alterations occur in brain structures anatomically remote from the stimulated site (McNamara et al., 1985). In the present studies, c-fos mRNA expression is evident throughout hippocampal formation and in PC following a class 5 seizure evoked by either angular bundle or amygdala stimu- lation; in contrast, c-fos mRNA expression is increased in amygdaloid nuclei following class 5 seizures evoked by amygdaloid but not angular bundle stimulation. We suggest that IEG ex: pression in the common structures may underlie the phenotypic alterations of transfer.

The constitutive levels of IEG expression were unchanged 28 $\mathrm{d}$ following the last class 5 seizure kindled from the angular bundle. However, the absence of a long-lasting change in IEG expression in kindled animals does not exclude a role for IEGs in the maintenance of kindling. The sequential albeit transient elevation of IEG expression during kindling development can be hypothesized to alter the expression of certain target genes. Once induced, these alterations in target gene expression would not necessarily require a persistent elevation in IEG expression.

The identity of the target genes whose expression is controlled by the seizure-evoked expression of IEGs remains elusive. Genes encoding neurotrophic factors and their receptors represent one attractive class of target genes whose expression is regulated by IEGs. The seizure-induced transcriptional activation of these genes (Gall and Isackson, 1989; Gall et al., 1991; Riva et al., 1992; Rocamora et al., 1992; Bengzon et al., 1993; Gall, 1993; Kiessling and Gass, 1993; Follesa et al., 1994) together with their pleiotropic effects on neuronal structure and function strengthens the candidacy of these particular genes. The localization of the IEG expression following kindled seizures to a distinct subset of nuclei will facilitate search for these target genes.

\section{References}

Amaral DG (1993) Emerging principles of intrinsic hippocampal organization. Curr Opin Neurobiol 3:225-229.

Angel P, Allegretto EA, Okino ST, Hattori K, Boyle WJ, Hunter 'I', Karin M (1988) Oncogene $j u n$ encodes a sequence-specific trans-activator similar to AP-1. Nature 332:166-171.

Bengzon J, Kokaia Z, Ernfors P, Kokaia M, Leanza G, Nilsson OG, Persson H, Lindvoll O (1993) Regulation of neurotrophin and trkA, trkB and trkC tyrosine kinase receptor messenger RNA expression in kindling. Neuroscience 53:433-446.

Bonhaus DW, Walters JR, McNamara JO (1986) Activation of substantia nigra neurons: role in the propagation of seizures in kindled rats. J Neurosci 6:3024-3030.

Bonhaus DW, Russell RD, McNamara JO (1991) Activation of substantia nigra pars reticulata neurons: role in the initiation and behavioral expression of kindled seizures. Brain Res 545:41-48.

Cain DP, Corcoran ME (1981) Kindling with low-frequency stimulation: generality, transfer, and recruiting effects. Exp Neurol 73:219232.

Cline HT, Constantine-Paton M (1990) NMDA receptor agonist and antagonists alter retinal ganglion cell arbor structure in the developing frog retinotectal projection. J Neurosci 10:1197-1216.

Cotman CW, Nadler JV (1978) Reactive synaptogenesis in the hippocampus. In: Neuronal plasticity (Cotman CW, ed), pp 227-271. New York: Raven.

Curran T, Gordon MB, Rubino KL, Sambucetti LC (1987) Isolation and characterization of the c-fos (rat) cDNA and analysis of posttranslational modifications in vitro. Oncogene 2:74-87.

DeOlmos J, Hardy H, Heimer L (1978) The afferent connections of the main and the accessory olfactory bulb formations in the rat: an experimental HRP study. J Comp Neurol 181:213-244.

Dragunow M, Robertson HA (1987) Kindling stimulation induces c-FOS protein(s) in granule cells of the rat dentate gyrus. Nature 329: 441-442.

Duchowny MS, Burchfiel JL (1981) Facilitation and antagonism of kindled seizure development in the limbic system of the rat. Electroencephalogr Clin Neurophysiol 51:403-416.

Engel J, Wolfson L, Brown L (1978) Anatomical correlates of electrical and behavioral events related to amygdaloid kindling. Ann Neurol 3:538-544.

Follesa P, Gale K, Mocchetti I (1994) Regional and temporal pattern 
of expression of nerve growth factor and basic fibroblast growth factor mRNA in rat brain following electroconvulsive shock. Exp Neurol $127: 37-44$.

Gall CM (1993) Seizure-induced changes in neurotrophin expression: implications for epilepsy. Exp Neurol 124:150-166.

Gall CM, Isackson PJ (1989) Limbic seizures increase neuronal production of messenger RNA for nerve growth factor. Science 245:758761.

Gall C, Lauterborn J, Bundman M, Murray K, Isackson P (1991) Seizures and the regulation of neurotrophic factor and neuropeptide gene expression in brain. Epilepsy Res [Suppl] 4:225-245.

Goddard GV, McIntyre D, Leech CK (1969) A permanent change in brain function resulting from daily electrical stimulation. Exp Neurol 25:295-330.

Goelet P, Castellucci VF, Schacher S, Kandel ER (1986) The long and the short of long-term mcmory-a molccular framcwork. Nature 322: $419-422$.

Hosford DA, Simonato M, Cao Z, Shin C, Butler LS, McNamara JO (1990) Anatomic distribution of c-fos, c-jun and NGFI-A mRNA following a kindling afterdischarge (AD). Soc Neurosci Abstr 16:847.

Hosford DA, Cao Z, Shin C, Butler LS, Rigsbee LC, McNamara JO (1991) Anatomic distribution of the immediate early gene $c$-fos in amygdala kindling. Neurology [Suppl 1] 41:51.

Hubel $\mathrm{DH}$, Wiesel TN (1965) Binocular interaction in striate cortex of kittens reared with artificial squint. J Neurophysiol 28:1041-1059.

Kiessling M, Gass P (1993) Immediate early gene expression in experimental epilepsy. Brain Pathol 3:381-393.

King GL, Dingledine R, Giacchino JL, McNamara JO (1985) Abnormal neuronal excitability in hippocampal slices from kindled rats. J Neurophysiol 54:1295-1304.

Krettek JE, Price JL (1978a) Amygdaloid projections to subcortical structures within the basal forebrain and brainstem in the rat and cat. J Comp Neurol 178:225-254.

Krettek JE, Price JL (1978b) A description of the amygdaloid complex in the rat and cat with observations on intra-amygdaloid axonal connections. J Comp Neurol 178:255-280.

Labiner DM, Butler LS, Cao Z, Hosford DA, Shin C, McNamara JO (1993) Induction of c-fos mRNA by kindled seizures: complex relationship with neuronal burst-firing. J Neurosci 13:744-751.

Lerea LS, McNamara JO (1993a) NMDA receptors activate transcription of c-fos and NGFI-A by distinct PLA2 requiring intracellular signaling pathways. Soc Neurosci Abstr 19:23.

Lerea LS, McNamara JO (1993b) Ionotropic glutamate receptor subtypes activate c-fos transcription by distinct calcium-requiring intracellular signaling pathways. Neuron 10:31-41.

Lerea LS, Butler LS, McNamara JO (1992) NMDA and non-NMDA receptor-mediated increase of c-fos mRNA in dentate gyrus neurons involves calcium influx via different routes. J Neurosci 12:29732981.

Maragos WF, Penney JB, Young AB (1988) Anatomic correlation of NMDA and ${ }^{3} \mathrm{H}$-TCP-labeled receptors in rat brain. J Neurosci 8:493501.

Mars NJ, Lopes da Silva FH (1983) Propagation of seizure activity in kindled dogs. Electroencephalogr Clin Neurophysiol 56:194-209.

Martin D, McNamara JO, Nadler JV (1992) Kindling enhances sensitivity of CA3 hippocampal pyramidal cells to NMDA. J Neurosci 12: 1928-1935.

McIntyre DC, Wong RK (1986) Cellular and synaptic properties of amygdala-kindled pyriform cortex in vitro. J Neurophysiol 55:12951307.

McNamara JO, Bonhaus DW, Shin C, Crain BJ, Gellman RL, Giacchino JL (1985) The kindling model of epilepsy: a critical review. CRC Crit Rev Neurobiol 1:341-392.

McNamara JO, Russell RD, Rigsbee L, Bonhaus DW (1988) Anticonvulsant and antiepileptogenic actions of MK-801 in the kindling and electroshock models. Neuropharmacology 27:563-568.

Milbrandt J (1987) A nerve growth factor-induced gene encodes a possible transcriptional regulatory factor. Science 238:797-799.

Milbrandt J (1988) Nerve growth factor induces a gene homologous to the glucocorticoid receptor gene. Neuron 1:183-188.

Mody I, Heinemann U (1987) $N$-methyl-D-asparlate (NMDA) receptors of dentate gyrus granule cells participate in synaptic transmission following kindling. Nature 326:701-704.

Monaghan DT, Cotman CW (1985) Distribution of $N$-methyl-D-aspartate-sensitive $\mathrm{L}-\left[{ }^{3} \mathrm{H}\right]$-glutamate-binding sites in rat brain. $\mathbf{J}$ Neurosci 5:2909 2919.

Morgan JI, Cohen DR, Hempstead JL, Curran T (1987) Mapping patterns of c-fos expression in the CNS after seizure. Science 237:192197.

Okazaki MM, McNamara JO, Nadler JV (1990) Kainate and quisqualate receptor autoradiography in rat brain after angular bundle kindling. Neuroscience 37:135-142.

Ottersen JP (1982) Connections of the amygdala of the rat: IV. Corticoamygdaloid and intraamygdaloid connections as studied with axonal transport of horseradish peroxidase. J Comp Neurol 205:30-48.

Pellegrino LJ, Cushman AJ (1967) A stereotaxic atlas of the rat brain. New York: Apple-Century-Crofts.

Price JL, Russchen FT, Amaral DG (1987) The limbic region. II: The amygdaloid complex. In: Handbook of chemical neuroanatomy, Vol 5, Integrated systems of the CNS, Pt I (Björklund A, Hökfelt T, Swanson LW, eds), pp 279-388. Amsterdam: Elsevier.

Racine RJ (1972) Modification of seizure activity by electrical stimulation: II. Motor seizure. Electroencephalogr Clin Neurophysiol 32: 281-294.

Ranck JB (1975) Which elements are stimulated in electrical stimulation of mammalian CNS: a review. Brain Res 98:417-440.

Represa A, Jorquera I, Le Gal La Salle G, Ben-Ari Y (1993) Epilepsy induced collateral sprouting of hippocampal mossy fibers: does it induce the development of ectopic synapses with granule cell dendrites? Hippocampus 3:257-268.

Riva MA, Gale K, Mocchetti I (1992) Basic fibroblast growth factor mRNA increases in specific brain regions following convulsive seizures. Brain Res Mol Brain Res 15:311-318.

Rocamora N, Palacios JM, Mengod G (1992) Limbic seizures induce a differential regulation of the expression of nerve growth factor, brain-derived neurotrophic factor and neurotrophin-3, in the rat hippocampus. Brain Res Mol Brain Res 13:27-33.

Saffen DW, Cole AJ, Worley PF, Christy BA, Ryder KA, Baraban JM (1988) Convulsant-induced increase in transcription factor mRNAs in rat brain. Proc Natl Acad Sci USA 85:7795-7799.

Shatz CJ (1990) Impulse activity and the patterning of connections during CNS development. Neuron 5:745-756.

Shin C., Scialabba FA, McNamara JO (1987) Stimulation of substantia nigra pars reticulata enhances dentate granule cell excitability. Brain Res 411:21-27.

Shin C, Cohen DR, McNamara JO, Morgan JI, Curran T (1990) Expression of c-fos mRNA in rat hippocampus is regulated by afterdischarge in the kindling model of epilepsy. J Neurochem 55:1050 1055 .

Simonato M, Hosford DA, Shin C, Mansbach HH, McNamara JO (1991) Differential expression of immediate early genes in the hippocampus in the kindling model of epilepsy. Mol Brain Res 11:115124.

Snedecor GW, Cochran WG (1980) Statistical methods, 7th ed. Ames City: Iowa State UP.

Sutula T, He XX, Cavazos J, Scott G (1988) Synaptic reorganization in the hippocampus induced by abnormal functional activity. Science 239:1147-1150.

Swanson LW (1976) An autoradiographic study of the efferent connections of the preoptic region in the rat. J Comp Neurol 167:227256.

Swanson LW, Köhler O, Björklund A (1987) The limbic region. II: The amygdaloid complex. In: Handbook of chemical neuroanatomy, Vol 5, Integrated systems of the CNS, Pt I (Björklund A, Hökfelt T, Swanson LW, eds), pp 125-277. Amsterdam: Elsevier.

Tauck DL, Nadler JV (1985) Evidence of functional mossy fiber sprouting in the hippocampal formation of kainic acid-treated rats. $J$ Neurosci 5:1016-1022.

Watanabe Y, Johnson RS, Butler LS, Spiegelman BM, Papaioannou VE, McNamara JO (1994) Null mutation of c-fos impairs functional and structural plasticities in the mammalian nervous system. Soc Neurosci Abstr 20: 1432.

Witter MP, Amaral DG (1991) Entorhinal cortex of the monkey: V. Projections to the dentate gyrus, hippocampus, and subicular complex. J Comp Neurol 307:437-459. 